\title{
Fixing fractures of the ulnar styloid in distal radius fractures
}

\author{
Marcos Sanmartin Fernandez \\ From 10th Congress of the Asia-Pacific Federation of Societies of Surgery fo the Hand and the 6th Congress \\ of Asia-Pacific Federation of Societies of Hand Therapists \\ Kuala Lumpur, Malaysia. 2-4 October 2014
}

The majority of distal radius fractures are associated with an ulnar styloid fracture [1-3]. There is solid evidence in the literature that this association may ultimately affect the clinical outcome causing instability, disability, and pain in the distal radioulnar joint (DRUJ) [2,4-7]. The main reasons for the worse outcome are: (1) DRUJ instability, (2) impingement with the triquetrum, and (3) Extensor Carpi Ulnaris (ECU) tenosynovitis.

Because of its close association with the Triangular Fibrocartilage Complex (TFCC), fractures of the ulnar styloid might indicate possible TFCC disruption with subsequent DRUJ instability $[4,8,9]$. Studies on the clinical relevance of ulnar styloid fractures have produced conflicting results. However, when considering size and displacement of the fracture, May et al [2] found that, after distal radius fracture stabilization, a fracture through the base of the ulnar styloid that involves most part of the TFCC attachment and stays in a deviated more radial position ( $2 \mathrm{~mm}$ or more) indicates DRUJ instability. In an ulnar styloid fracture model, Shaw et al [4] found that K-wire fixation of the ulnar styloid fracture restored stability to the DRUJ regardless the integrity of other supporting structures.

Bone fragments resulting from non-union could also provoke irritation and pain $[5,10]$ due to impingement with the triquetrum [11]. Twenty-six percent of ulnar styloid fractures develop non-union [12]. From those, just a few becomes symptomatic [5]. If the DRUJ is stable, simple removal of the fragment usually solves the problem [5,11]. Extensor carpi ulnaris tendon impingement caused by malalignment of a fibrous nonunion may also be responsible for a poor clinical outcome. [13,14]. This condition is rarely found after a distal radius fracture and it is successfully treated with excision of the bony prominence

\footnotetext{
Department of Orthopaedics and Traumatology, Hospital Povisa, Vigo, 36211,
} Spain

\section{References}

Frykman G: Fracture of the distal radius including sequela: shoulderhand-finger syndrome, disturbance in the distal radioulnar joint and impairment of nerve function. Acta Orthop Scand 1967, 108(suppl):1-153.

2. May MM, Lawton JN, Blazar PE: Ulnar styloid fractures associated with distal radius fractures: incidence and implications for distal radioulnar joint instability. J Hand Surg Am 2002, 27(6):965-971.

3. Villar RN, Marsh D, Rushton N, Greatorex RA: Three years after Colles' fracture. A prospective review. J Bone Joint Surg Br 1987, 69(4):635-638.

4. Shaw JA, Bruno A, Paul EM: Ulnar styloid fixation in the treatment of posttraumatic instability of the radioulnar joint: a biomechanical study with clinical correlation. J Hand Surg Am 1990, 15(5):712-720.

5. Hauck RM, Skahen J 3rd, Palmer AK: Classification and treatment of ulnar styloid nonunion. J Hand Surg Am 1996, 21(3):418-422.

6. Orhun H, Dursun M, Gürkan V, Sario E, Altun G, Akça O: A new index for the assessment of distal radius fractures involving the ulnar styloid. Acta Orthop Traumatol Turc 2011, 45(4):261-265.

7. Krämer S, Meyer H, O'Loughlin PF, Vaske B, Krettek C: The incidence of ulnocarpal complaints after distal radial fracture in relation to the fracture of the ulnar styloid. J Hand Surg Eur Vol 2013, 38(7):710-717.

8. Af Ekenstam F, Jakobsson OP, Wadin K: Repair of the triangular ligament in Colles' fracture: no effect in a prospective randomized study. Acta Orthop Scand 1989, 60(4):393-396.

Lindau T, Arner M, Hagberg L: Intraarticular lesions in distal fractures of the radius in young adults. J Hand Surg 1997, 22(5):638-643. 
10. Burgess RC, Watson HK: Hypertrophic ulnar styloid nonunions. Clin Orthop Relat Res 1988, 228: 215-217

11. Protopsaltis and Ruch. 2010.

12. Bacorn RW, Kurtzke JE: Colles' fracture: a study of two thousand cases from the New York State Workmen's Compensation Board. J Bone Joint Surg Am 1953, 35-A(3):643-658.

13. Crimmins CA, Jones NF: Stenosing tenosynovitis of the extensor carpi ulnaris. Ann Plast Surg 1995, 35(1):105-107.

14. Kiyono Y, Nakatsuchi Y, Saitoh S: Ulnar-styloid nonunion and partial rupture of extensor carpi ulnaris tendon: two case reports and review of the literature. J Orthop Trauma 2002, 16(9):674-677.

doi:10.1186/1753-6561-9-S3-A43

Cite this article as: Fernandez: Fixing fractures of the ulnar styloid in

distal radius fractures. BMC Proceedings 2015 9(Suppl 3):A43.

Submit your next manuscript to BioMed Central and take full advantage of:

- Convenient online submission

- Thorough peer review

- No space constraints or color figure charges

- Immediate publication on acceptance

- Inclusion in PubMed, CAS, Scopus and Google Scholar

- Research which is freely available for redistribution

Submit your manuscript at www.biomedcentral.com/submit 